\title{
Caring as a core concept in educating midwifery learners: A qualitative study
}

\begin{abstract}
Authors:
Mmajapi E. Chokwe ${ }^{1}$

Susan C.D. Wright ${ }^{1}$

Afflliations:

${ }^{1}$ Adelaide Tambo School of

Nursing Science, Tshwane

University of Technology

Correspondence to:

Mmajapi Chokwe

Email:

chokweme@tut.ac.za

Postal address:

PO Box 911-1569, Rosslyn

0200, South Africa

Dates:

Received: 31 Jan. 2012

Accepted: 13 July 2012

Published: 27 Nov. 2012

How to cite this article: Chokwe, M.E. \& Wright, S.C.D., 2012, 'Caring as a core concept in educating midwifery learners: A qualitative study', Health SA Gesondheid 17(1), Art. \#653, 7 pages. http://dx.doi. org/10.4102/hsag.v17i1.653
\end{abstract}

(C) 2012. The Authors. Licensee: AOSIS OpenJournals. This work is licensed under the Creative Commons Attribution License.
Caring is the core business of nursing and midwifery, involving a relationship in which the carer is committed to the needs of the one being cared for (Mason-Whitehead, Mcintosh, Bryan \& Mason). Caring is the emotion which drives a midwife to care, the motive aimed at assisting someone to grow and self-actualise (Watson). The concern in midwifery is that irrespective of caring being central to the midwifery profession, caring taught in theoretical learning does not always translate into caring behaviour in practice. A qualitative exploratory study examined how midwifery educators impart the skill of caring during theoretical learning and clinical accompaniment, in order to respond to the general complaint made both locally and internationally that midwives are uncaring. The aim was to explore caring during theoretical learning and clinical accompaniment from the perspective of midwifery educators. Participants in the study were midwifery educators teaching midwifery in institutions of learning in Tshwane, South Africa. The naive sketch was used to gather data, wherein one central question was asked and the educators were invited to narrate and respond. Three themes emerged: the meaning of caring; how caring was conveyed during theoretical learning; and how it was conveyed during clinical accompaniment. Although the midwifery educators expressed how they conveyed caring to the learner midwives, it was not evident how caring competencies were assessed in order to ensure caring midwives at the end of training.

Omgee is die kernwaarde van 'n verpleegkundige en vroedvrou. Omgee behels 'n verhouding waar die person wat omgee verbind is om in die behoeftes van die een wat sorg benodig te voldoen (Mason-Whitehead, Mcintosh, Bryan \& Mason). Omgee is die emosie wat die vroedvrou noop om om te gee, om 'n person te help groei en self-aktualiseer (Watson). Die kwelpunt in verloskunde is dat ongeag van die sentrale belang van omgee vir verloskundiges, die teoretiese onderig oor omgee nie altyd uitgeleef word in die praktyk nie. 'n Kwalitatiewe ondersoekende studie het die wyse ondersoek waarop vroevrou opvoerders die vaardigheid om om te gee, oordra tydens teoretiese en kliniese begeleiding, ten einde te reageer op die plaaslike en internasionale algemene klagte, dat vroedvroue nie omgee nie. Om omgee tydens teoreties en kliniese onderrig vanuit die perspektief van die opvoedkundige verloskundige te ondersoek. Die deelnemers het bestaan uit verloskundige opvoedkundiges wat verloskunde doseer in hoër onderwys institusies in Tshwane, Suid-Afrika. 'n Naïewe skets is gebruik om data in te samel met een sentrale vraag. Drie temas het voortgespuit: die betekenis van omgee; hoe die konsep oorgedra is tydens teoretiese onderrig; en hoe die konsep oorgedra is tydens kliniese onderrig. Alhoewel die verloskundige opvoedkundiges kon verduidelik hoe hulle omgee oorgedra het aan die leerling vroedvroue, was daar geen bewyse van hoe omgee vaardighede evalueer is nie ten einde omgee vaardige vroedvroue aan die professie te lewer.

\section{Introduction}

The International Confederation of Midwives (ICM) competency of midwifery educators' position statement (ICM 2008:1) and global standards for midwifery education (ICM 2010:5) state that midwifery educators need to be role models and competent practitioners who can apply the model of caring to those they teach. Furthermore, the ICM states that midwifery educators are guardians of safe, competent and respectful midwifery care, and must understand their own values in order to create an environment which emphasises caring attributes (ICM 2008:1).

Although the concept of caring is abstract and difficult to measure (Karaöz 2005:32; Watson \& Foster 2003:363), it implies having a great interest in and strong feelings and concern for others, and a belief in an individual's worth and uniqueness (Watson 2007:132). It is the ability to accept people unconditionally and respect their dignity as humans, showing empathy and sympathy and being non-judgemental (Mulaudzi, Mokoena \& Troskie 2001:95). 
Caring is holistic care. Watson (2007:130) expresses the holistic nature of caring as the interplay of mind-body-spirit, and identifies 10 factors of caring known as the Theory of Human Caring. These carative factors include a focus on value systems, sensitivity, transpersonal relationships, support and gratification of human needs, use of scientific problem solving processes in decision making, installation of faith and hope, promotion of an interpersonal teachinglearning environment, and achievement of the helping-trust relationship (Jesse 2006:103; Meadows 2007:159; Watson 2007:131).

Literature expresses the importance of installing caring into midwifery in order to ensure that midwives understand how to incorporate caring in their daily care. However, theoretical teaching of caring is not so easy and does not always translate into caring in practice, resulting in a dissonance between caring in the classroom and in practice (Chokwe, Wright \& Erasmus 2010:148; Meadows 2007:160). Watson and Foster (2003:364) agree, mentioning that integration of theory and practice in midwifery is a challenge for learner midwives, because the human element of caring has been lost and replaced by impersonal, highly technical, modern midwifery care. To ensure that the learner midwives are caring on completion of training the curriculum must include 'caring science' (Chokwe et al. 2010:148). If caring defines nursing and midwifery, it is imperative that caring and its attributes be included in the curriculum throughout midwifery subjects.

The Regulations Relating to the Approval, Education and Training of a Nurse (R425) in South Africa state that the curriculum must ensure that the learner shows respect for the dignity and uniqueness of human beings in their socialcultural context at the end of training (South African Nursing Council 1985). The midwifery curriculum must involve the dimensions of the art and science of midwifery caring, and the responsibility of nursing educators is to contribute to the clarification of caring and to develop midwifery curricula which achieve desirable caring behaviour (Karaöz 2005:39).

The challenge facing midwifery educators is to facilitate the processes through which learner midwives can be socialised into caring as the professional foundation for midwifery. The educators must provide learners with the necessary tools during theoretical learning which can increase their understanding of caring, to ensure qualified, sensitive, caring professionals (Chokwe et al. 2010:3). This article examines what caring is and how midwifery educators impart caring to learner midwives during theoretical learning and clinical accompaniment, in the hope of ensuring caring professionals at the end of training.

\section{Problem statement}

Midwifery educators must provide learners with the necessary tools during theoretical learning and clinical accompaniment to increase their understanding of caring and ensure that sensitive, caring professionals are qualified at the end of midwifery training (Chokwe et al. 2010:3). Given the challenge facing midwifery education and caring, the researcher aimed to facilitate the processes through which learner midwives were socialised into caring, by holding debriefing sessions about caring in midwifery clinical experience. It was in these sessions that the learner midwives expressed the view that the clinical environment was uncaring and hostile, and was not promoting or supporting the correlation of midwifery caring from theory into clinical practice. Perry (2009:37) states that a positive clinical environment and role-modelling support promote the positive integration of theory into clinical practice, and contribute to future development of the profession and caring.

This current article is part of a study about caring which revealed incidents of uncaring behaviour during midwifery clinical practice (Chokwe et al. 2010), based on findings from an investigation of the methods which midwifery educators used to install caring into learners, in order to ensure that at the end of training caring would ultimately be displayed by novice and qualified midwives.

This study seeks to identify gaps which may have contributed to some of the uncaring behaviours experienced by the learner midwives during their clinical practice, in the hope of identifying recommendations for improvement.

\section{Objectives of the study}

The objectives of the study were to explore how midwifery educators conveyed caring to learner midwives during theoretical teaching and clinical accompaniment. The study also aimed to identify the gaps in teaching caring which may have contributed to uncaring behaviours experienced by the learner midwives during their clinical practice.

\section{Theoretical foundation of the study}

The philosophy of Swanson's Theory of Caring is the theoretical basis of this study. Swanson defined the Theory of Caring (Dickson 1996:20) as promoting the way of relating to others, feeling a personal sense of commitment and responsibility towards the other as a valued individual, with five key elements:

- Maintaining belief: promoting faith and trust to empower someone to pass through an event and face the future with positive meaning.

- Knowing: striving to understand an event as it has meaning to the other.

- Being with: being emotionally present for the other;

- Doing for: helping an individual to perform a task independently if able to.

- Enabling: making it possible for someone to pass through an unfamiliar life event or transition.

Swanson's theory is applicable in this study because whilst socialising the learner midwives into professionalism, a supportive, protective, theoretical-clinical environment must be created such that it enables, maintains and cultivates caring, trust and sensitivity (Chokwe et al. 2010:5). 


\section{Contribution to the field}

The study was designed to explore caring during theoretical learning and clinical accompaniment from the midwifery educators' perspective. The article focuses on stimulating a debate about concerns about caring within the midwifery community in South Africa and internationally, owing to public complaints about uncaring behaviours during midwifery clinical practice.

\section{Research methods and deign Design}

The research design was qualitative and exploratory (Creswell 2007:36), and aimed at understanding and explaining the meaning which the participants gave to caring in their everyday lives.

\section{Context of the study}

The study was conducted at a nursing college and a university in Tshwane, South Africa, amongst educators teaching midwifery. All the midwifery educators were approached and invited to participate in the study.

\section{Population}

The target population was educators teaching midwifery in nursing colleges and universities in Tshwane, South Africa, the inclusion criteria being educators employed as midwifery educators in institutions of learning in Tshwane who were willing to participate.

The sampling method used was a census sample; the midwifery educators at the identified institutions were approached, and all agreed to participate in the study. The sample size realised was $10(n=10)$.

\section{Data collection method}

The naive sketch, a self-report technique where participants narrate their experiences and perceptions in written format, answering a specific question, was selected to gather data from the midwifery educators. Speziale and Carpenter (2007:41) define narrative writing as the systematic documentation of a person's experiences and perceptions. Narratives can be used in place of, or in addition to, an interview and was preferred in this population group as it allowed participants time to compose their thoughts about what they wished to share, and provided rich, comprehensive data (Speziale \& Carpenter 2007:41). The designed naive sketch was used to invite midwifery educators to elucidate on how they convey caring to the learner midwives during theoretical learning and clinical accompaniment. The question posed was: From your personal experience and perception as a midwifery educator, what does caring mean to you and how do you convey caring to your learner midwives during theoretical learning and clinical accompaniment?

The naive sketch requests were sent to the educators electronically where possible, and hard copies were hand- delivered to specific participants. After being briefed about the objectives of the study, willing participants signed an informed consent form. The midwifery educators were given a month to complete the narratives and the completed sketches were collected for analysis. One naive sketch was not returned. The instrument was pre-tested before commencing with the data gathering by issuing the naive sketch to three midwifery educators from a nursing training college not included in the study. No adjustments were made to the instrument following the pre-test.

\section{Data analysis}

Analysis commenced immediately from the time the first naive sketch was collected. The hermeneutic interpretive method (Speziale \& Carpenter 2007:88) was used to analyse the data and comprised a three-step process: naive reading, which involves reading the whole to become familiar with the text; structural analysis, which involves interpretive reading where data are arranged according to meaningful units; and interpretation of the whole by reflecting on the initial reading along with the interpretive reading, where the meaning units are arranged into themes and subthemes. Nine naive sketches were used for the demographic profile and seven were analysed qualitatively. Two sketches were not analysed since continued analysis yielded no new information, indicating that saturation level had been reached.

\section{Results}

\section{Findings on midwifery educators' perspective of caring}

The findings on caring are presented in terms of the demographic profile of the participants and the findings generated from the data.

\section{Demographic profile of the participants}

The sample size was nine participants $(n=9)$. The 41-50-year age group had the most participants $(n=4)$. More than half of the group $(n=6)$ were from the Tswana socio-cultural group, followed by the South Sotho socio-cultural group with two $(n=2)$. Most of the participants $(n=8)$ had more than 16 years of experience in midwifery education.

\section{Findings from the naive sketches}

The themes and categories generated from the data are presented in Table 1.

\section{The meaning of caring}

The data generated concepts perceived as caring and categorised as attending to individuals' needs, showing respect for humankind, and caring as an expression of professionalism.

Attending to individuals' needs: According to the midwifery educators' perceptions, caring means identifying and attending to learner midwives' needs. They emphasised that attending to someone's needs to the best of one's ability 
TABLE 1: Themes and categories generated from the midwifery educators' data.

\begin{tabular}{ll}
\hline Themes & Categories \\
\hline The meaning of caring & $\begin{array}{l}\text { Attending to an individuals' needs } \\
\text { Showing respect for humankind } \\
\text { Caring is an expression of professionalism }\end{array}$ \\
\begin{tabular}{ll} 
Conveying caring during theoretical & Being a good role model and showing respect \\
learning & Providing individualised attention and care \\
& Being supportive \\
& Being competent and proficient \\
Conveying caring during clinical & Respect for individuality \\
accompaniment & Being compassionate, kind and approachable \\
& Being conscientious \\
\hline
\end{tabular} \\
\hline
\end{tabular}

and providing individualised education demonstrated caring. They mentioned that the ability to recognise the need for affection and dignity for another meant caring. Caring was taking care of those who were helpless. One participant wrote:

'Caring means to look after someone and being sensitive to their needs.' (P1)

'It means making sure that all her needs are attended to appropriately.' (P1)

Showing respect for humankind: The participants mentioned that reinforcing the culture of respecting human dignity in the learner midwives by asking permission from the patient before performing procedures and giving findings in a language understandable to the patient showed respect and caring. The participants remarked:

'Respect for individuality and being sensitive to people's values and demonstrating humaneness is caring.' (P3)

'Caring is respect for the individuality of persons.' (P3)

'Caring is the ability to respect the norms, values, culture and religion of patients.' (P5)

'The culture of respecting human dignity and keeping confidentiality regarding medical issues of the patient is part of caring.' (P6)

Caring is an expression of professionalism: Caring is displayed by identifying the learner midwives' needs and ensuring one remains competent in the profession's current body of knowledge. It means recognising that the learner midwives are social beings with social roles, allowing them to reflect on their learning and thus nurturing them. The participants mentioned that caring was conveying kindness and making someone accepted, as well as expressing love for the profession. The participants wrote:

'When nurses love the profession, they will love their job and they will care for their learner midwives whole-heartedly.' (P2)

'The ethics of the profession determines the ideal professional behaviour; principles like beneficence and respect promote caring.' (P4)

\section{Conveying caring during theoretical learning}

The concepts categorised under conveying caring during theoretical learning included being a good role model and showing respect, providing individualised attention and care, being supportive, and being competent and proficient.

Being a good role model and showing respect: Caring is demonstrated by creating a therapeutic milieu in the teaching environment, including encouraging the learner midwives to love their profession and exercising patience when topics are discussed. The participants wrote:

'By being committed to one's work, thereby giving your time and service and holistic attention to the other.' (P1)

'Being kind; interacting with courtesy amongst learner midwives and reinforcing positive human relations demonstrates caring.' (P2)

'Preparing yourself well before going to class and showing respect for students and that is caring.' (P4)

Providing individualised attention and care: Caring includes showing concern by enquiring about someone's well-being and giving words of encouragement when someone feels down. A balance between emotions and actions should be maintained within the educator-learner relationship. The participants elaborated that attending to the learner midwives with learning problems, including individual consultations with specific objectives and counselling those failing and performing poorly, shows caring:

'Making myself available and attending to those students with specific learning problems demonstrates caring.' (P7)

'Exposing learner midwives to different learning opportunities, and assisting them to overcome their learning problems, through remediation sessions, constitutes caring.' (P7)

Being supportive: Allowing the learner midwives to interact with the educator, by voicing their work-integrated learning experiences freely through debriefing sessions, is incorporated in caring. Other measures include having an open-door policy for consultation, active listening and providing learner midwives with the opportunity to evaluate the facilitation and teaching. The participants declared:

'Caring is the ability to help another with love.' (P7)

'Keeping an open-door policy with or without assigning specific appointments for learners demonstrates caring.' (P5)

'By giving students lecturers' contact numbers enabling them to consult when they have learning problems, is caring.' (P4)

Being competent and proficient: According to the participants, caring includes being knowledgeable and skilful as an educator: using demonstration, role-playing, debriefing, reflections and narratives as alternative methods of teaching constituted caring. Discussing scenarios of caring in the classroom, allowing learner midwives to roleplay caring behaviours and remediate uncaring behaviours, demonstrated caring. Other aspects of caring mentioned by participants included orientation of the learner midwives and keeping accurate records of learning content, being prepared before teaching and marking scripts fairly, ensuring learner materials and guides were ready on registration, and the educators making themselves available during self-study activities. Some narratives were as follows:

'When midwives maintain relevant knowledge, caring is facilitated.' (P5)

'By continuing to study, reading and keeping updated with information demonstrates caring.' (P5)

'The ability to perform accurate assessment and making good decisions to meet the learner's needs demonstrates caring.' (P7) 


\section{Conveying caring during clinical accompaniment}

The categories realised included respect for individuality, being compassionate, kind and approachable, and being conscientious.

Respect for individuality: According to the participants' perceptions, caring meant encouraging the learner midwives to demonstrate respect by addressing patients by their names and respecting their culture and beliefs. They mentioned that the way in which they demonstrated procedures to the learner midwives, showing respect and understanding, illustrated caring. Furthermore, they held that the respect and understanding they showed to learner midwives, and clinicians who are resourceful in learning-teaching in the clinical area, demonstrated caring:

'Patients should not be taken as objects of the students practice. Clinical practice should be geared to attaining the best care at the most comfortable technique.' (P1)

'Showing respect to students and patients during accompaniment conveys a strong message of caring to students. If they observe a good trait in the accompanist, they will try to implement these caring behaviours in future.' (P1)

Being compassionate, kind and approachable: The midwifery educators elaborated that caring meant realising a holistic approach to learner midwives' needs and providing them with physical, psychological and social support. They mentioned that caring defined the nursing-midwifery profession, as did expressively demonstrating caring with a warm touch, low tone of voice and body language inherent in nursing care. Caring is demonstrated by accompanying learner midwives with the aim of assisting them and ensuring that they meet their set learning objectives. According to the participants, reinforcing the spirit of being non-judgemental and being sensitive towards another person's feelings indicated caring:

'By guiding the learner midwives to acknowledge the severity of the pain of labour irrespective of the stage in which the patient is in, and responding by giving analgesia demonstrates caring.' (P3)

'By demonstrating to the learner that they allow the contraction to fade away before continuing with abdominal examination, respecting the patient's level of judgement to the discomfort is caring.' (P5)

'By giving a healing touch, being compassionate, kind and gentle and friendly to learner midwives, demonstrates caring'. (P7)

'A midwifery educator who cares for her learner midwives is able to empathise with them during difficulty.' (P3)

Being conscientious: Caring is demonstrated through appropriate accompaniment of learner midwives during the patient's labour process, including supporting the learner midwife physically, psychologically and providing privacy when demonstrating procedures or when reprimanding. The participants elaborated that keeping medical issues and patients' diagnoses confidential indicated caring. According to the participants' experience, reinforcing provision of privacy to learner midwives also showed caring:
'The way in which I express myself in front of the student shows how much I care about their progress and achievement.' (P2)

'Caring is the midwife's ability to listen responsively, showing empathy and communicating supportive words.' (P3)

'The way I ask permission from the patient before demonstrating the procedure and the respect that I give to the patient by pulling up the curtains demonstrate caring to the student.' (P2)

\section{Ethical considerations}

Approval was granted by the Research and Ethics Committee of the University (reference number 2006/10/025), the Gauteng Department of Health Research Unit, and the heads of the institutions of learning identified. The principles of respect for persons, autonomy, beneficence, justice, confidentiality and anonymity were adhered to (Brink 2006:30-48). In addition, the participants gave written informed consent to take part in the study, and were allowed to terminate their participation without facing any penalty should they wish to do so.

\section{Trustworthiness}

The principles as proposed by Lincoln and Guba (1985: chapter 11) were considered:

- Credibility: Reflects the accuracy of the participants' experiences in the study and includes activities which increase the probability that credible findings will be produced.

- Transferability: Refers to the probability that the findings have meaning to others in similar situations of study.

- Confirmability: The process of recording the findings in such a way as to leave an audit trail which can be followed by other researchers (Speziale \& Carpenter 2007:49).

\section{Discussion}

Although caring is as old as mankind, the literature indicates that 'caring science' was first described in the 1900s. The caring theories guide midwifery-nursing on what caring is and how it can be conveyed to learner midwives and patients (Dickson 1996:22; Karaöz 2005:32; Watson \& Foster 2003:363).

\section{The meaning of caring}

Karaöz (2005:32) suggests that caring is a state in which a nurse is a person living, growing, caring and deliberately and genuinely in attendance of another. Alternatively, Watson (2007) defined caring as an ethical model of nursing characterised by protection, enrichment and preservation of human dignity (Jesse 2006; Karaöz 2005:32). According to Leininger (1997, cited in Karaöz (2005:31), caring has biophysical, psychological, cultural, social and environmental scope, and all must be applied to ensure provision of holistic care to people.

Caring is cultural, and therefore in order to meet the needs of others, one must practice both cultural sensitivity and awareness. The common thread which weaves through the caring theories mentioned is that they all highlight humanism, 
and nursing is based on a human science perspective (Karaöz 2005:32). The purpose of midwifery education is to provide a theoretical and clinical experience which will shape and develop learner midwives into caring professionals.

The midwifery educators in this study defined caring as attending to individuals' needs, showing respect for humankind and caring as an expression of professionalism. The study on Turkish students' perceptions of caring (Karaöz 2005:34) supports this caring study, since the students identified respect as the fundamental aspect of caring. The midwifery educators' viewpoint of attending to the learners' needs is in agreement with Swanson's theory, which states that caring is being emotionally present for the other, enabling someone to pass through an unfamiliar life event (Dickson 1996:21). In a study about educating for care (Bassett 2001: 64), the educators viewed caring as a positive connection of teacher and student, whilst the students expressed that those who were exposed to a caring educational climate had the potential of displaying the same caring in clinical practice, therefore reinforcing the caring, nurturing and valuing of students as an act of promoting professionalism.

\section{Conveying caring during theoretical learning and clinical accompaniment}

The midwifery educators reflected a theoretical knowledge and understanding of the popular meaning of caring (Chokwe et al. 2010:150). Being a good role model, providing individualised attention and care, being supportive, competent and proficient were concepts which midwifery educators narrated as ways of conveying caring during theoretical facilitation. This notion is supported by Swanson's theory of promoting faith and trust to empower the other, by being emotionally present which enables a person to face the future with a positive meaning (Dickson 1996:23).

Creating a therapeutic milieu in the teaching environment was mentioned in this caring study, and the same is stated in Watson's Theory of Human Caring, which stipulates that caring is the promotion of a positive interpersonal teachinglearning environment (Jesse 2006:103; Watson 2007:132). This study indicated how midwifery educators taught caring during theoretical learning or clinical accompaniment, through role-play and discussion of caring scenarios. The findings of this study are in agreement with that entitled 'Educating for care' (Bassett 2001:64), which suggests that if caring is the core business of midwifery, it should be a fundamental concept in the midwifery-nursing curriculum and therefore be formally taught to learners.

Respect for individuality, being compassionate, kind, approachable and conscientious were the categories conveying caring during clinical accompaniment mentioned by the midwifery educators. There is mutual agreement with the ICM competencies, which state that the midwifery educators ought to be guardians of safe, competent and respectful midwifery care, creating an environment of value clarification for the learner midwives (ICM 2008:1). The study with Turkish students also indicated that being compassionate, showing love and sharing feelings are important attributes of caring (Karaöz 2005:31).

In addition, this caring study indicated that remediating uncaring behaviours of the learner midwives in private signified caring during clinical accompaniment (Chokwe et al. 2010:150). This notion is supported by a study about evaluation of caring education, which indicated a significant increase in Taiwanese students' caring behaviours after participating in the specific educational caring programme (Li-Min, Chi-Chun \& Chung-Hey 2009:873). However, this caring study (Chokwe et al. 2010) did not reflect how the caring competencies were assessed and attained by the learner midwives. Since there has been global outcry in previous studies and general public complaints about uncaring behaviours in midwifery in South Africa, incorporating caring in teaching should be a priority (Abrahams, Jewkes \& Mvo 2001:245; Begley 2001:225; Rafii, Oskouie \& Nikravesh 2007:301).

This caring study did not demonstrate when the subject of caring in the midwifery curriculum was introduced to learner midwives, or whether caring was integrated within the major subjects of midwifery. One of the key features of Swanson's Caring Theory is promoting faith and trust, being emotionally present, and making it possible for someone to go beyond an unfamiliar life event. Therefore, failure to integrate caring is in conflict with this theory. It is further noted in the literature that irrespective of the theoretical teaching of caring offered, it does not always translate into caring practice since there is a difference between classroom and practice. Watson and Foster (2003:363) attribute this distinction to the challenge that learner midwives have in integrating caring theory into practice in midwifery.

Sadly, the human element of midwifery caring has also been replaced by an impersonal, highly technical medical model of care, whilst caring outcomes in practice depend on teaching the learning processes of midwifery caring (Chokwe et al. 2010:149). This concept is supported by Griffiths (2008:329) in an editorial debate responding to whether caring in midwifery is lost or not, where he states that caring is challenged by worldwide human suffering and the social and technological systems surrounding midwifery care.

According to this caring study, the midwifery educators focused on respect, as this concept was mentioned in the three themes which emerged from the data analysis (Chokwe et al. 2010:149). The same opinion is held by Gallagher (2007:369), who emphasises that respect is both other-regarding and a self-regarding desirable quality of human relationships involving engagement. The study revealed that respect requires effort, paying attention, getting to know all of their individuality, active listening and working with the other appropriately (Gallagher 2007:366). Swanson agrees with the fact that caring is striving to understand an event as it has meaning to the other (Dickson 1996: 23). 
A question for exploration in future research is the role of respect in caring from the midwifery educators' perspective, and whether they equate caring to respect. Although the midwifery educators exhibited perfect knowledge of what caring was, their own inherent caring behaviour could not be explored due to time constraints (Chokwe et al. 2010:150).

\section{Limitations for the study}

The limitation of this study was the use of only one datagathering method. The study could have benefitted if individual interviews or focus groups were used to enrich the data.

\section{Recommendations}

The recommendations that emerged from this study are related to practice, research and nursing education.

Midwifery training must include and emphasise the affective aspect of caring in the curriculum and assess caring behaviours, before registration with the South African Nursing Council. Research should be conducted to explore the relationship between respect and caring from the perspective of midwifery ducators.

\section{Conclusion}

The midwifery curriculum must include the dimensions of the art and science of midwifery caring, and aim at rolemodelling caring in the classroom and in practice. The responsibilities of midwifery educators are to develop midwifery curricula with the affective aspect of midwifery as the core, incorporate caring in daily teaching and clinical accompaniment, and assess caring competencies during clinical practice, which hopefully will achieve desirable caring behaviour.

\section{Acknowledgements}

We would like to acknowledge the Gauteng Department of Health for granting me permission to approach and interview the midwifery educators at the college. The project would not have been possible without Mrs T.S. Ramukumba's guidance and influence in conceptualisation of the study and the cooperation of the midwifery educators who took part in the study.

\section{Competing interests}

The authors declare that they have no financial or personal relationship(s) which may have inappropriately influenced them in writing this article.

\section{Authors' contribution}

M.E.C. (Tshwane University of Technology) was responsible for the writing of the manuscript, data gathering and analysis. S.C.D.W. (Tshwane University of Technology) was responsible for supervision and guidance in the project, interpretation of findings and scientific writing.

\section{References}

Abrahams, N., Jewkes, R. \& Mvo, Z., 2001, 'Health care-seeking practices of pregnant women and the role of the midwife in Cape Town', Journal of Midwifery and Women's Health 46(4), 240-247. http://dx.doi.org/10.1016/S15269523(01)00138-6

Bassett, C., 2001, 'Educating for care, a review of the literature', Nurse Education in Practice 1, 64-72. http://dx.doi.org/10.1054/nepr.2001.0009 PMid:19036246

Begley, C.M., 2001, "'Knowing your place: Student midwives" views of relationships in midwifery in Ireland', Midwifery Journal 17(1), 222-233. http://dx.doi. org/10.1054/midw.2001.0262 PMid:11502142

Brink, H., 2006, Fundamentals of research methodology for health care professionals, 2nd edn., Juta, Cape Town.

Chokwe, M.E., Wright, S.C.D. \&. Erasmus, D.G.J., 2010, Perceptions and experiences of caring in midwifery, Tshwane University of Technology, Pretoria.

Creswell, J.W., 2007, Qualitative inquiry and research design: Choosing among five approaches, 2 nd edn., Sage, Thousand Oaks.

Dickson, N., 1996, 'A theory of caring for midwifery', Australian College of Midwives Incorporated 9(2), 20-24.

Gallagher, A., 2007, 'The respectful nurse', Nursing Ethics 14(3), 360-370.

Griffiths, P., 2008, 'The art of losing, a response to the question is caring a lost art', International Journal of Nursing Studies 45, 329-332.http://dx.doi.org/10.1016/j. ijnurstu.2007.09.008 PMid:1802178

International Confederation of Midwives (IMC), 2008, 'Competencies for midwifery educators', viewed 26 July 2011, from http://www.internationalmidwives.org

International Confederation of Midwives (IMC), 2010, 'Global standards for midwifery education', viewed 30 November 2011, from http:// www.internationalmidwives. org

Jesse, E., 2006, 'Watson's philosophy of nursing practice', in M.R. Alligood \& A.M. Tomey (eds.), Nursing theory utilisation and application, pp. 103-129, Elsevier, Philadelphia.

Karaöz, S., 2005, 'Turkish nursing students perceptions of caring', Nurse Education Today 25(1), 31-40. http://dx.doi.org/10.1016/j.nedt.2004.09.010 PMid:15607245

Li-Min W., Chi-Chun, C. \& Chung-Hey, C., 2009, 'Evaluation of a caring education for Taiwanese nursing students, a quasi-experiment with before and after comparison', Nurse Education Today 29, 873-878. http://dx.doi.org/10.1016/j.nedt.2009.05.006 PMid:19505747

Lincoln, Y.S. \& Guba, E.G., 1985, Naturalistic inquiry, Sage, CA.

Mason-Whitehead, E., Mcintosh, A. \& Bryan, A. \& Mason, T., 2008, Key concepts in nursing, Sage, Thousand Oaks.

Meadows, R., 2007, 'Beyond caring', Nurse Administration Quarterly 31(2), 158-161.

Mulaudzi, M., Mokoena, J. \& Troskie, R., 2001, Basics in nursing ethics, Clyson, Cape Town.

Perry, R.N.B., 2009, 'Role modelling excellence in clinical nursing practice', Nurse Education in Practice 9, 36-44. http://dx.doi.org/10.1016/j.nepr.2008.05.001 PMid:18590978

Rafii, F., Oskouie, F. \& Nikravesh, M., 2007, 'Caring behaviours of burn nurses and the related factors', viewed 20 March 2010, from http://www.boimedcentral. com/1472-690306

South African Nursing Council, 1985, 'Regulations relating to the approval of and the minimum requirements for the education and training of a nurse (general, psychiatric and community) and midwife leading to Registration', Government Notice No. R.425 as amended, 22 April 1988, viewed 14 October 2008, from http://www.sanc.co.za/regulat/Reg-cem.htm

Speziale, H.J.S. \& Carpenter, D.R., 2007, Qualitative research in nursing: Advancing the humanistic imperative, 4 th edn., Lippincott, Philadelphia.

Watson, J. \& Foster, R., 2003, 'The attending nurse caring model: Integrating theory, evidence and advanced caring-healing therapeutics for transforming professional practice', Journal of Clinical Nursing 12, 360-365.

Watson, J., 2007, 'Watson's theory of human caring and subjective experiences: Carative factors', Texto Contexto Enfermagem 16(1), 129-135. http://dx.doi. org/10.1590/S0104-07072007000100016 